\title{
Correction to: Better beware: comparing metacognition for phishing and legitimate emails
}

\section{Casey Inez Canfield ${ }^{1}$ (D) Baruch Fischhoff ${ }^{2} \cdot$ Alex Davis $^{2}$}

Published online: 13 September 2019

(C) The Author(s) 2019

\section{Correction to: Metacognition and Learning (2019) https://doi.org/10.1007/s11409-019-09197-5}

The article "Better beware: comparing metacognition for phishing and legitimate emails", written by Casey Inez Canfield, Baruch Fischhoff and Alex Davis, was originally published electronically on the publisher's internet portal (currently SpringerLink) on 20 July 2019 without open access.

With the author(s)' decision to opt for Open Choice the copyright of the article changed on September 2019 to (C) The Author(s) 2019 and the article is forthwith distributed under the terms of the Creative Commons Attribution 4.0 International License (http://creativecommons. org/licenses/by/4.0/), which permits use, duplication, adaptation, distribution and reproduction in any medium or format, as long as you give appropriate credit to the original author(s) and the source, provide a link to the Creative Commons license and indicate if changes were made.

Open Access This article is distributed under the terms of the Creative Commons Attribution 4.0 International License (http://creativecommons.org/licenses/by/4.0/), which permits unrestricted use, distribution, and reproduction in any medium, provided you give appropriate credit to the original author(s) and the source, provide a link to the Creative Commons license, and indicate if changes were made.

Publisher's note Springer Nature remains neutral with regard to jurisdictional claims in published maps and institutional affiliations.

The online version of the original article can be found at https://doi.org/10.1007/s11409-019-09197-5

Casey Inez Canfield

canfieldci@mst.edu

1 Missouri University of Science \& Technology, 300 W 13th St, Rolla, MO 65409, USA

2 Carnegie Mellon University, 5000 Forbes Avenue, Pittsburgh, PA 15213, USA 